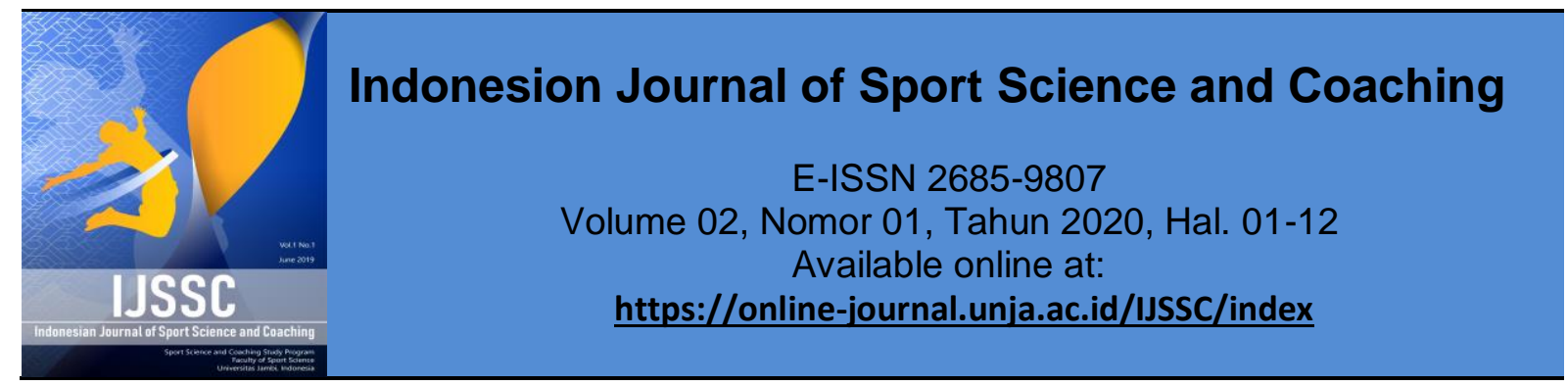

Research Article

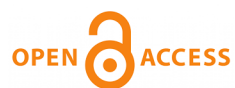

\title{
Upaya Meningkatkan Hasil Pembelajaran Gerak Dasar Lompat Melalui Pendekatan Bermain Lompat Lingkar Berwarna
}

\author{
(Efforts to Improve Learning Basic Learning Outcomes Through Approach to Playing Colored \\ Levels)
}

\author{
Hendri Munar", Ely Yuliawan \\ Jurusan Pendidikan Olah Raga dan Kepelatihan, FKIP, Universitas Jambi \\ Kampus Pinang Masak JI. Raya Jambi-Ma.Bulian KM.15 Mendalo Indah, \\ Kec. Jaluko, Kab. Muarojambi-Jambi, Indonesia Kode Pos 36361 \\ ${ }^{*}$ Correspondence Author: hendrimunarfik@unja.acid
}

\begin{tabular}{|c|c|}
\hline Informasi Artikel & ABSTRACT \\
\hline $\begin{array}{l}\text { Submit: } 08-10-2019 \\
\text { Diterima: } 13-02-2020 \\
\text { Dipublikasikan: } 25-02-2020\end{array}$ & $\begin{array}{l}\text { The implementation of long jump learning in grade II students of } \\
\text { SD } 76 \text { / IX Muaro Jambi is unsatisfactory for Physical Education } \\
\text { teachers, the results obtained by students based on observations } \\
\text { on the basic motion learning Jump are still many students whose } \\
\text { grades do not meet the minimum Minimum Mastery Criteria } \\
\text { (KKM) standards that have been set. This situation triggers the } \\
\text { author in conducting further research. The type of research to be } \\
\text { carried out is classroom action research. The model used in this } \\
\text { study is the Kemmis and Mc Taggart models. This model was } \\
\text { chosen because the results of research using this model can be } \\
\text { used as consideration for improving and perfecting the basic } \\
\text { motion of jumping at SD Negeri } 76 \text { / IX Muaro Jambi. The results } \\
\text { of classroom action research in the first cycle and analysis can } \\
\text { be concluded that the increase in the results of the long jump } \\
\text { through playing colored circle jumps in grade II students of SD } \\
\text { Negeri } 76 \text { I IX Muaro Jambi was marked by an increase in the } \\
\text { average value of students. The average value of students in pre- } \\
\text { action activities is } 60 \% \text { with a percentage of completeness of } \\
40 \% \text {. This condition has increased the average value of students } \\
\text { in the first cycle with a percentage of completeness of } 93 \% \text {. This } \\
\text { shows that the predetermined targets have been achieved so } \\
\text { that the research is carried out in only one cycle. The basic jump } \\
\text { motion learning process uses a play approach that is dynamic } \\
\text { and fun. Students actively carry out the task and observe the } \\
\text { basic movement techniques of jumping and mutual discussion } \\
\text { with friends. All aspects of assessment are controlled by } \\
\text { students. The basic jumping ability of students increases marked } \\
\text { by almost all students completing KKM (Minimum completeness } \\
\text { criteria), that is } 75 \text {. } \\
\text { Key words: Long jump, Classroom action, Basic jump technique }\end{array}$ \\
\hline Penerbit & ABSTRAK \\
\hline $\begin{array}{l}\text { Jurusan Pendidikan Olah Raga dan } \\
\text { Kepelatihan FKIP Universitas Jambi, } \\
\text { Jambi- Indonesia }\end{array}$ & $\begin{array}{l}\text { Pelaksanaan pembelajaran lompat jauh pada siswa kelas II SD } \\
\text { Negeri } 76 / \text { IX Muaro Jambi kurang memuaskan bagi guru } \\
\text { Penjas, hasil yang didapatkan siswa berdasarkan observasi } \\
\text { pada pembelajaran gerak dasar Lompat masih banyak siswa } \\
\text { yang nilainya belum memenuhi standar Kriteria Ketuntasan } \\
\text { Minimal (KKM) yang telah ditetapkan. Keadaan ini yang }\end{array}$ \\
\hline
\end{tabular}



Penelitian yang akan dilaksanakan adalah penelitian tindakan kelas (classroom action research).Model yang digunakan dalam penelitian ini adalah model Kemmis dan Mc Taggart. Model ini dipilih karena hasil penelitian dengan menggunakan model ini dapat digunakan sebagai bahan pertimbangan untuk memperbaiki dan menyempurnakan gerak dasar lompat di SD Negeri 76/IX Muaro Jambi. Hasil penelitian tindakan kelas pada siklus pertama dan dilakukan analisis dapat disimpulkan bahwa peningkatan hasil lompat jauh melalui bermain lompat lingkar berwarna pada siswa kelas II SD Negeri 76/IX Muaro Jambi ditandai dengan peningkatan nilai rata- rata siswa. Nilai ratarata siswa pada kegiatan pratindakan sebesar $60 \%$ dengan persentase ketuntasan sebesar $40 \%$. Kondisi tersebut mengalami peningkatan nilai rata-rata siswa pada siklus I dengan persentase ketuntasan sebesar 93\%. Hal tersebut menunjukkan bahwa target yang telah ditetapkan sebelumnya sudah tercapai sehingga penelitian dilakukan hanya satu siklus saja. Proses pembelajaran gerak dasar lompat menggunakan pendekatan bermain berlangsung dinamis dan menyenangkan. Peserta didik aktif melaksanakan tugas dan mengamati gerakan teknik gerak dasar lompat dan saling diskusi dengan teman. Seluruh aspek penilaian dikuasai peserta didik. Kemampuan gerak dasar lompat peserta didik meningkat dengan ditandai hampir seluruh peserta didik tuntas KKM (Kriteria Ketuntasan Minimal) yaitu 75.

Kata kunci: Lompat jauh, Tindakan kelas, Teknik dasar lompat

This Indonesian Journal of Sport Science and Coaching is licensed under a CC BY-NC-SA (Creative Commons Attribution-ShareAlike 4.0 International License)

\section{PENDAHULUAN}

IImu Usia sekolah dasar merupakan masa-masa yang sangat menentukan pertumbuhan dan perkembangan fisik serta gerak yang memegang peranan penting dalam pembentukan individu yang berkualitas dikemudian hari(Purwandini, K., \& Kartasurya, M. I., 2013). Pendidikan jasmani tidaklah mungkin terlepas dari belajar, untuk lebih spesifiknya dinamakan "pembelajaran" melalui pembelajaranlah anak dapat mengetahui lebih banyak hal, disinilah anak dididik dan dibina untuk menjadi manusia yang berkulitas dari yang tidak bisa menjadi bisa, dari yang tidak tahu menjadi tahu (Christiari, A. Y., Syamlan, R., \& Kusuma, I. F., 2013). Jenis permainan yang akan diteliti adalah permainan beregu, karena permainan ini lebih mudah diterapkan dan sesuai dengan karakter usia anak SD. Permainan tersebut mempunyai tujuan untuk meningkatkan kesegaran jasmani salah satunya yang berhubungan dengan kemampuan gerak dasar lokomotor. Pembelajaran pendidikan jasmani di SD Negeri 76/IX Muaro Jambi, terutama kelas II masih menggunakan pembelajaran konvensional, dari hasil observasi di lapangan saat pembelajaran masih menggunakan peralatan dan keterampilan yang sebenarnya, contohnya lari memutari lapangan, jalan keliling kampung, melompat ke bak pasir. sering kali dilaksanakan di jalan kampung sekitar sekolah. Melalui pendekatan 
bermain lompat lingkar berwarna diharapkan para siswa menemukan suasana baru yang menyenangkan dengan suasana yang menyenangkan siswa akan lebih tertarik dan senang dalam mengikuti pembelajaran, sehingga siswa lebih aktif bergerak. PTK ini merupakan upaya untuk mengetahui seberapa besar optimalnya penggunaan pendekatan bermain lompat lingkar berwarna terhadap peningkatan kemampuan gerak dasar melompat anak. Untuk mengetahui apakah permainan beregu dapat mengoptimalkan kemampuan gerak dasar lokomotor, maka perlu dilakukan Penelitian Tindakan Kelas dengan judul, " Upaya meningkatkan hasil pembelajaran gerak dasar lompat melalui pendekatan bermain lompat lingkar berwarna pada siswa kelas II SD Negeri 76/IX Muaro Jambi". Berdasarkan identifikasi masalah dan pembatasan masalah tersebut di atas diajukan rumusan masalah sebagai berikut "Apakah melalui pendekatan bermain lompat lingkar berwarna dapat meningkatkan hasil gerak dasar melompat pada siswa kelas II SD Negeri 76/IX Muaro Jambi.

Berdasarkan tingkat perkembangan motorik manusia, perkembangan motorik manusia dibagi menjadi empat tahapan perkembangan sampai proses kematangan gerak, yaitu : (a) Reflexive movement phase, (b) Rudimentary movement phase, (c) Fundamental movement phase, (d) Specialized movement phase. Sesuai dengan teori perkembangan gerak yang dikemukan oleh martin, pada gambar dibawah akan memberikan gambaran fase perkembangan fisik anak berdasarkan usianya jelas tergambar bahwa koordinasi gerak tidak diberikan pada usia tersebut akan menghambat gerak untuk mempelajari gerak yang labih komleks lagi, dan untuk jangka panjang saat dewasa kelak akan menghambat aktifitas fisik dalam menghadapi kehidupan sahari-hari (Farida, A., 2016)

Tabel 2. Indikator Perkembangan Berbagai Macam Faktor Fisik Yang Dikembangkan Pada Usia Anak- Anak Dan Remaja

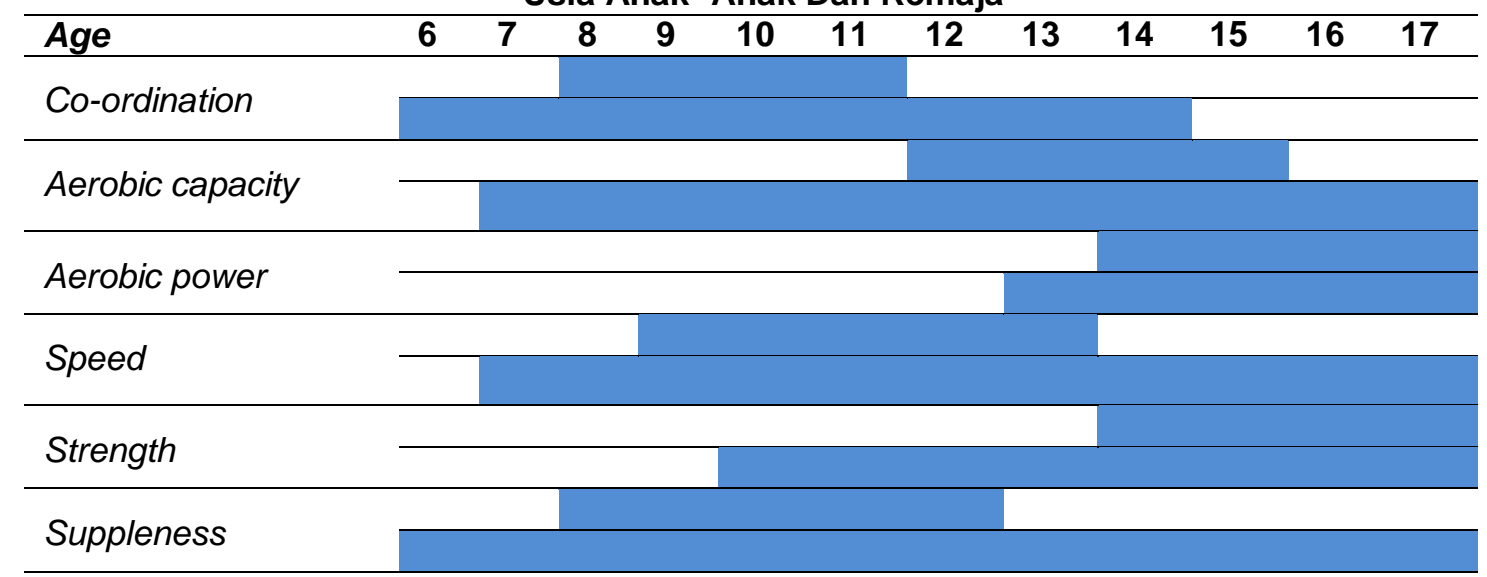

Sumber : FIFA Coaching, (FIFA, Switzerland, 2010)

Gerak dasar atau dalam terminologi perkembangan motorik tersebut dengan istilah fundamental movement melibatkan unsu-unsur dasar pergerakan tertentu dari satu gerakan saja. Itu tidak meliputi hal-hal seperti gaya (style) seseorang atau keaneh- keanehan pribadi didalam malakukan satu gerak tertentu. Contoh gerak dasar yang perlu dikembangkan pada masa anak-anak adalah berlari, mleompat, 
bergeser kesamping, sedangkan gerak manipulatif dapat berupa melempar, menangkap, menendang, dan mendorong, dan mendorong, kesemuanya adalah bagian dari gerakan-gerakan lanjut dari gerak dasar yang lebih kompleks (Handoko, A. H., \& Pandiangan, D. S, 2019). Dengan berolahraga hidup akan menjadi sehat (Wibowo, Y. G., \& Indrayana, B., 2019).

\section{METODE PENELITIAN}

Jenis Penelitian yang akan dilaksanakan adalah penelitian tindakan kelas (classroom action research). Model yang digunakan dalam penelitian ini adalah model Kemmis dan Mc Taggart. Gambar berikut ini merupakan alur penelitian dari model Kemmis dan Mc Taggart.
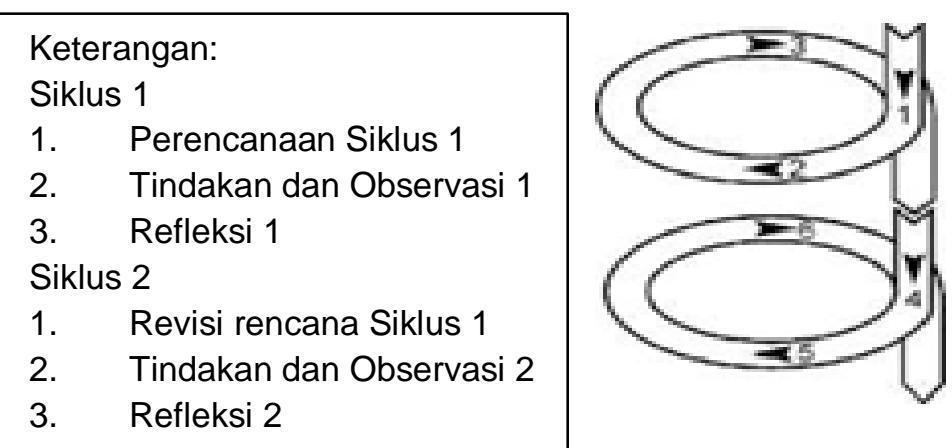

Gambar 1: Model Kemmis dan Mc Taggart (Pardjono, dkk., 2007: 22)

Berdasarkan model Kemmis dan Mc Taggart, tahapan penelitian dilakukan meliputi: (1) Refleksi Awal : Pada tahap ini dilakukan identifikasi kesulitan siswa dalam memahami gerak dasar lompat. (2) Perencanaan Tindakan: Masalah yang ditemukan akan diatasi dengan melakukan langkah-langkah perencanaan tindakan yaitu menyusun instrumen penelitian berupa: Rencana Program Pembelajaran (RPP), Angket, Lembar Observasi, dan Intrumen Penilaian. (3) Pelaksanaan Tindakan: Pada tahap ini dilakukan tindakan berupa pelaksanaan program pembelajaran, pengambilan atau pengumpulan data hasil angket, lembar observasi dan hasil tes. Dan (4) Observasi, Refleksi, dan Evaluasi: Tahap ini dilakukan untuk mengumpulkan data-data dan menganalisisnya untuk kemudian dapat diambil kesimpulan dari penelitian ini.

\section{HASIL PENELITIAN DAN PEMBAHASAN}

Penelitian yang dilaksanakan di kelas II SD Negeri 76/IX Muaro Jambi diawali dengan kegiatan observasi bagaimana cara siswa melakukan gerak dasar lompat dan cara mengajar guru. Berdasarkan observasi dalam pembelajaran penjas, khususnya gerak dasar lompat menggunakan metode yang kurang tepat, guru hanya memberi contoh kepada siswa tetapi tanpa adanya latihan yang dapat merangsang siswa untuk melakukan gerak dasar lompat. Guru juga mengatakan kesulitan yang biasanya ditemui yaitu siswa mengalami kesulitan dalam melakukan gerak dasar lompat. Hasil tes awal yang dilakukan pada siswa kelas II SD Negeri 76/IX Muaro Jambi jumlah siswa 30, baru 11 siswa yang tuntas KKM, yaitu 75 untuk penjasorkes. 
Kegiatan pratindakan ini dilakukan oleh 30 siswa dengan rincian 16 siswa laki-laki dan 14 siswa perempuan. Hasil tes pratindakan dapat dilihat pada tabel 2 .

Tabel.2. Hasil Tes Pratindakan

\begin{tabular}{|c|c|c|c|c|c|c|c|c|c|}
\hline \multirow[t]{2}{*}{ No } & \multirow[t]{2}{*}{ Nama Siswa } & \multicolumn{4}{|c|}{ Nilai } & \multirow[b]{2}{*}{5} & \multirow[b]{2}{*}{6} & \multirow{2}{*}{$\begin{array}{l}\text { Nilai } \\
\text { Akhir }\end{array}$} & \multirow[t]{2}{*}{ Ket } \\
\hline & & 1 & 2 & 3 & 4 & & & & \\
\hline 1 & Abhiyana Alfiandra & 70 & 70 & 71 & 78 & 70 & 70 & 72 & TT \\
\hline 2 & Anisa Rahmawati & 71 & 70 & 77 & 76 & 73 & 72 & 73 & TT \\
\hline 3 & Afifi Abdul Aziz & 70 & 70 & 73 & 78 & 70 & 71 & 72 & TT \\
\hline 4 & Aufar Pratama & 78 & 76 & 77 & 76 & 73 & 73 & 76 & $T$ \\
\hline 5 & Aqila Nur Hafifah & 78 & 79 & 79 & 76 & 72 & 71 & 76 & $\mathrm{~T}$ \\
\hline 6 & Aqila Safira & 72 & 70 & 74 & 75 & 71 & 70 & 72 & TT \\
\hline 7 & Ayla Azuhra & 71 & 71 & 74 & 78 & 70 & 70 & 72 & TT \\
\hline 8 & Azelia Malaika Z. & 79 & 78 & 76 & 77 & 72 & 72 & 76 & $T$ \\
\hline 9 & Choiron Nuril Huda & 78 & 76 & 78 & 78 & 71 & 72 & 76 & $\mathrm{~T}$ \\
\hline 10 & Daffa Bramantio O. & 78 & 76 & 78 & 77 & 74 & 71 & 76 & $T$ \\
\hline 11 & Daniah Salsabila & 71 & 71 & 74 & 78 & 71 & 70 & 73 & TT \\
\hline 12 & Devinna Galantry & 70 & 71 & 73 & 78 & 72 & 72 & 73 & TT \\
\hline 13 & Fahril Saputra & 70 & 70 & 75 & 76 & 73 & 71 & 73 & TT \\
\hline 14 & Ghata Febryan & 70 & 70 & 74 & 79 & 70 & 73 & 73 & TT \\
\hline 15 & Intan Sunny B. & 71 & 70 & 74 & 78 & 72 & 71 & 73 & TT \\
\hline 16 & Mario Yghgzkhiel O. & 72 & 70 & 76 & 74 & 70 & 70 & 72 & TT \\
\hline 17 & M. Iqbal Zada Arrafif & 78 & 77 & 78 & 76 & 74 & 72 & 76 & $\mathrm{~T}$ \\
\hline 18 & M. Khoiril Romza & 79 & 78 & 78 & 78 & 75 & 71 & 77 & $\mathrm{~T}$ \\
\hline 19 & M. Nabil Haniko P. & 71 & 70 & 78 & 78 & 70 & 70 & 74 & TT \\
\hline 20 & Muhammad Nur F. & 77 & 78 & 76 & 78 & 76 & 74 & 77 & $\mathrm{~T}$ \\
\hline 21 & M. Rabli Setiawan & 77 & 76 & 75 & 78 & 76 & 71 & 76 & $T$ \\
\hline 22 & Nurhasanah A. & 78 & 76 & 79 & 78 & 72 & 72 & 76 & $T$ \\
\hline 23 & Qaireen Diya R. & 71 & 70 & 76 & 76 & 70 & 72 & 73 & TT \\
\hline 24 & Raffino Vitra Alfarizi & 72 & 70 & 78 & 78 & 71 & 70 & 73 & TT \\
\hline 25 & Rahmat Saputra & 71 & 70 & 76 & 76 & 70 & 70 & 72 & TT \\
\hline 26 & Rifqig Hardisa Putra & 79 & 78 & 78 & 77 & 75 & 75 & 77 & $T$ \\
\hline 27 & Rossyanna & 72 & 75 & 73 & 75 & 70 & 72 & 73 & TT \\
\hline 28 & Salsabila Putri & 71 & 70 & 71 & 72 & 70 & 71 & 71 & TT \\
\hline 29 & Zaafera Aqila A. & 78 & 79 & 76 & 77 & 76 & 75 & 77 & $\mathrm{~T}$ \\
\hline & Zara Tian Putri & 71 & 72 & 73 & 72 & 72 & 70 & 72 & TT \\
\hline Rat & -Rata & 74 & 73 & 76 & 77 & 72 & 71 & 74 & \\
\hline Jum & & & & & & & & 2289 & \\
\hline Nila & Tertinggi & & & & & & & 77 & \\
\hline Nila & Terendah & & & & & & & 71 & \\
\hline Rat & - Rata Nilai Akhir & & & & & & & 74 & \\
\hline Per & entase Ketuntasan & & & & & & & $40 \%$ & \\
\hline
\end{tabular}


Keterangan :

1.Lompat tanpa awalan

2.Lompat ke samping kanan

3.Lompat ke samping kiri

4.Lompat ke depan

5.Lompat ke atas setinggi-tingginya

6.Lompat ke belakang

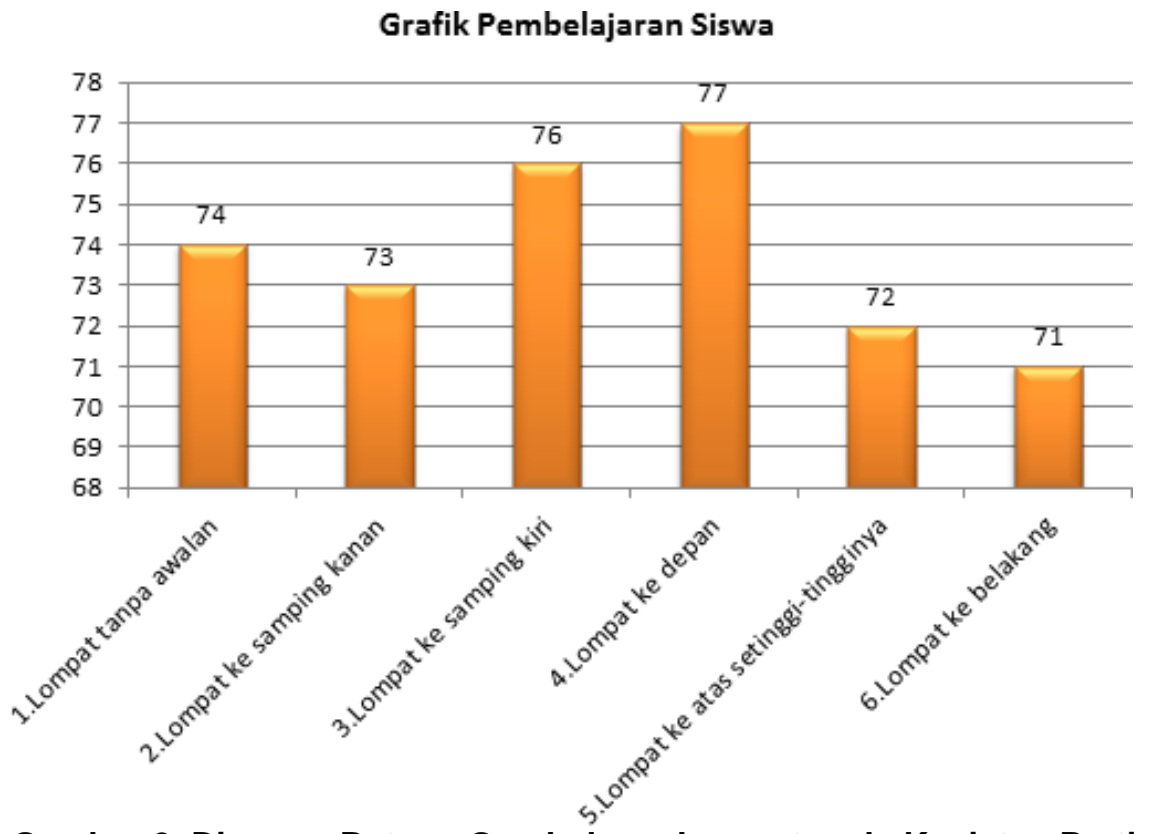

Gambar 2. Diagram Batang Gerak dasar Lompat pada Kegiatan Pratindakan

Hasil tes gerak dasar Siswa Kelas II SD Negeri 76/IX Muaro Jambi pada kegiatan pratindakan disajikan dalam bentuk diagram batang, untuk lebih jelasnya dapat dilihat pada gambar 2. Hasil nilai formatif pratindakan dapat dilihat pada tabel 3.

Tabel 3. Hasil nilai Formatif Pratindakan

\begin{tabular}{ccccc}
\hline Nilai & \multicolumn{2}{c}{ Banyak Siswa } & Jumlah Nilai \\
\hline 77 & 4 & & 308 \\
\hline 76 & 8 & \multicolumn{2}{c}{608} \\
\hline 75 & - & 74 & \\
\hline 74 & 1 & \multicolumn{2}{c}{657} \\
\hline 73 & 9 & 504 & \\
\hline 72 & 7 & 71 & \\
\hline 71 & 1 & \multicolumn{2}{c}{2222} \\
\hline Jumlah & 30 & 74 &
\end{tabular}

Berdasarkan hasil tes pratindakan diperoleh nilai rata-rata sebesar 74 . Jumlah siswa yang mencapai KKM hanya sebanyak 12 siswa ( 40\%) dan siswa yang belum mencapai KKM sebanyak 18 siswa (60\%). Dari tes pratindakan yang dilakukan diketahui bahwa ada beberapa siswa yang tidak mampu untuk melakukan gerak dasar lompat dengan benar baik dari sikap awal, pelaksanaan, dan sikap akhir.

\section{Hendri Munar \& Ely Yuliawan}


Berdasarkan data yang diperoleh dari tes pratindakan, peneliti, dan guru bermaksud untuk memperbaiki dan meningkatkan kemampuan siswa dalam melakukan gerak dasar lompat.

\section{Deskripsi Siklus I}

\section{Perencanaan Tindakan}

1) Melakukan identifikasi masalah dengan kolaborator sesama guru penjasorkes. Dalam hal ini diadakan sharing ideas tentang penelitian tindakan kelas (Action Reseach). Langkah ini diambil untuk membicarakan tentang rendahnya pencapaian hasil belajar gerak dasar lompat dari tes awal yang diambil dari hasil belajar gerak dasar lompat siswa Kelas II SD Negeri 76/IX Muaro Jambi sebagai subjek penelitian dan juga untuk mengambil langkah- langkah guna mengatasi hal tersebut. Pada sharing ideas ini juga dibahas tentang tujuan pembelajaran dengan pendekatan bermain dan bagaimana cara pelaksanaannya.

2) Merumuskan tindakan solusi dengan perencanaan pembelajaran lompat jauh dengan menggunakan pendekatan bermain lompat dengan lingkaran berwarna.

3) Menyiapkan alat yang akan digunakan, berupa lingkaran yang suah diberi warna.

\section{Pelaksanaan Tindakan}

Melaksanakan pembelajaran lompat jauh dalam bentuk permainan lompat bilah bambu dan lompat kardus. Permainan menekankan pada masalah tehnik awalan tumpuan melayang dan mendarat dengan rincian pelaksanaan kegiatan sebagai berikut:

1) Pendahuluan

a) Guru menyiapkan siswanya.

b) Guru menyampaikan tujuan pembelajaran

c) Guru menginformaikan model pembelajaran yang akan digunakan

d) Guru memberikaan apersepsi dengan menceritakan kegiatan bermain khususnya atletik.

2) Pemanasan

Pemanasan umum dengan cara bermain bolabong/bola tembak/ berburu kijang dimana siswa diberikan kebebasan untuk melakukan gerakan berlari dan melompat-lompat untuk menghindari supaya tidak terkena tembakan bola. Dari gerakan bermain tersebut sudah sesuai dengan pola gerak dasar dominan lompat jauh yaitu adanya gerakan berlari dan melompat, siswa melakukan dengan perasaan gembira.

3) Kegiatan Inti

1. Guru membagi 3 kelompok siswa, setiap kelompok mendapat 10 lingkaran berwarna. Masing masing siswa melakukan $3 x$ lompatan

2. Masih dalam kelompoknya, Siswa melakukan lompat sendiri secara bergantian di tempat dan maju ke depan. siswa melakukan sirkuit lompat lingkaran berwarna yang telah diletakkan dengan jarak bervariasi mulai dari 0,5 meter sampai 1 meter. Masing-masing siswa melakukan gerakan sebanyak $3 x$. 
3. Siswa dikumpulkan untuk melakukan diskusi tentang bagaimana cara melompat

4. Masing masing siswa melakukan gerakan lompat yang sesungguhnya.

5. Guru mencatat hasil lompatan siswa

6. Akhir dari kegiatan guru merekap hasil lompatan dan memilih lompatan terbaik yang diraih oleh tiga orang siswa, dan kepadanya diberikan penghargaan berupa pujian dan memberi motivasi pada siswa lain untuk lebih giat lagi dalam berlatih lompat jauh agar di kemudian hari dapat mencapai hasil yang lebih baik.

4) Penutup

a) Senam pelemasan

b) Guru memberikan umpan balik dan tanya jawab

c) Guru meminta siswa untuk mencatat hal hal yang berkesan, menarik, ataupun semua kekurangan dari pembelajaran ini sebagai refleksi dan evaluasi proses pembelajaran.

\section{Hasil Pengamatan}

Dari hasil pengamatan yang dilakukan kolaborator terhadap proses pembelajaran, setiap kemajuan yang terjadi baik pada siswa maupun suasana pembelajaran dicatat dan diperoleh sebagai berikut:

1. Guru peneliti sudah melaksanakan pembelajaran sesuai dengan RPP.

2. Siswa masih ragu-ragu dan belum siap melakukan bermain lompat

3. Hasil dari diskusi dan tanya jawab setelah melihat dan melakukan lompatan diperoleh jawaban sebagai berikut:

a. Berlatih melompati tali karet sesering mungkin.

b. Awalan dilakukan dengan kecepatan maksimal.

c. Melompat dengan tumpuan satu kaki.

d. Mendarat dengan dua kaki bersama sama dengan kedua tangan diayunkan dari atas ke depan.

4. Siswa belum terbiasa mengambil kesimpulan dari kegiatan yang dilakukan.

5. Pada saat bermain dan diskusi masih didominasi satu atau dua anak belum semua siswa berani mengeluarkan pendapatnya.

6. Masih ada materi yanng sulit dikuasai oleh siswa

\section{Refleksi}

Berdasarkan hasil observasi peneliti dan kolabolator melakukan refleksi sebagai berikut:

1. Guru lebih aktif mengawasi kegiatan siswa dan memancing partisipasi dalam mengikuti pembelajaran.

2. Siswa dipersiapkan terlebih dahulu dengan menyampaikan tugas tugas secara rinci dan lengkap sesuai dengan rencana.

3. Hasil belajar lompat jauh meningkat ditandai dengan 19 anak tuntas dibandingkan dengan keadaan sebelum siklus hanya 11 siswa yang tuntas.

4. Sebagian siswa masih asing dengan permainan lompat bilah bambu dan lompat kardus karena terbiasa dengan latihan lompat jauh sistem drill yang berulang ulang. 
5. Siswa belum maksimal dalam melaksanakan diskusi dan tanya jawab.

6. Peneliti perlu mengawasi siswa secara secara teliti dan cermat.

7. Peneliti belum maksimal dalam mengarahkan siswa dalam permainan.

Hasil tes Gerak dasar lompat Siswa Kelas II SD Negeri 76/IX Muaro Jambi pada kegiatan siklus I sebagaimana pada tabel 4 .

Tabel 4. Hasil Tes Lompat Gerak Dasar Siklus I

\begin{tabular}{|c|c|c|c|c|c|c|c|c|c|}
\hline \multirow[t]{2}{*}{ No } & \multirow[t]{2}{*}{ Nama Siswa } & \multicolumn{4}{|c|}{ Nilai } & \multirow[b]{2}{*}{5} & \multirow[b]{2}{*}{6} & \multirow{2}{*}{$\begin{array}{l}\text { Nilai } \\
\text { Akhir }\end{array}$} & \multirow[t]{2}{*}{ Ket } \\
\hline & & 1 & 2 & 3 & 4 & & & & \\
\hline 1 & Abhiyana Alfiandra & 88 & 83 & 82 & 85 & 70 & 77 & 81 & $\mathrm{~T}$ \\
\hline 2 & Anisa Rahmawati & 83 & 80 & 80 & 82 & 73 & 76 & 79 & $\mathrm{~T}$ \\
\hline 3 & Afifi Abdul Aziz & 78 & 74 & 73 & 75 & 72 & 71 & 74 & TT \\
\hline 4 & Aufar Pratama & 85 & 82 & 81 & 84 & 72 & 73 & 80 & $\mathrm{~T}$ \\
\hline 5 & Aqila Nur Hafifah & 89 & 84 & 82 & 85 & 74 & 75 & 82 & $\mathrm{~T}$ \\
\hline 6 & Aqila Safira & 87 & 83 & 82 & 83 & 76 & 75 & 81 & $\mathrm{~T}$ \\
\hline 7 & Ayla Azuhra & 82 & 80 & 80 & 84 & 75 & 75 & 79 & $\mathrm{~T}$ \\
\hline 8 & Azelia Malaika Z. & 86 & 85 & 83 & 85 & 74 & 76 & 82 & $\mathrm{~T}$ \\
\hline 9 & Choiron Nuril Huda & 85 & 84 & 82 & 83 & 73 & 75 & 80 & $\mathrm{~T}$ \\
\hline 10 & Daffa Bramantio O. & 88 & 86 & 85 & 86 & 72 & 75 & 82 & $\mathrm{~T}$ \\
\hline 11 & Daniah Salsabila & 87 & 85 & 83 & 85 & 71 & 74 & 81 & $\mathrm{~T}$ \\
\hline 12 & Devinna Galantry & 80 & 81 & 80 & 84 & 72 & 74 & 79 & $\mathrm{~T}$ \\
\hline 13 & Fahril Saputra & 86 & 85 & 82 & 85 & 73 & 75 & 81 & $\mathrm{~T}$ \\
\hline 14 & Ghata Febryan & 88 & 84 & 81 & 83 & 72 & 78 & 81 & $\mathrm{~T}$ \\
\hline 15 & Intan Sunny B. & 85 & 82 & 83 & 83 & 72 & 78 & 81 & $\mathrm{~T}$ \\
\hline & Mario Yghgzkhiel O. & 84 & 83 & 81 & 85 & 73 & 79 & 81 & $\mathrm{~T}$ \\
\hline & M. Iqbal Zada Arrafif & 83 & 82 & 82 & 83 & 74 & 76 & 80 & $\mathrm{~T}$ \\
\hline 18 & M. Khoiril Romza & 88 & 85 & 83 & 84 & 75 & 76 & 82 & $\mathrm{~T}$ \\
\hline 19 & M. Nabil Haniko P. & 80 & 78 & 74 & 74 & 70 & 70 & 74 & TT \\
\hline 20 & Muhammad Nur F. & 82 & 81 & 82 & 82 & 73 & 79 & 80 & $\mathrm{~T}$ \\
\hline 21 & M. Rabli Setiawan & 89 & 84 & 81 & 83 & 74 & 78 & 82 & $\mathrm{~T}$ \\
\hline 22 & Nurhasanah A. & 82 & 85 & 83 & 85 & 74 & 75 & 81 & $\mathrm{~T}$ \\
\hline 23 & Qaireen Diya R. & 89 & 87 & 85 & 83 & 73 & 76 & 82 & $\mathrm{~T}$ \\
\hline 24 & Raffino Vitra Alfarizi & 87 & 84 & 84 & 82 & 72 & 74 & 81 & $\mathrm{~T}$ \\
\hline 25 & Rahmat Saputra & 86 & 84 & 83 & 81 & 75 & 78 & 81 & $\mathrm{~T}$ \\
\hline 26 & Rifqig Hardisa Putra & 88 & 86 & 85 & 83 & 75 & 76 & 82 & $\mathrm{~T}$ \\
\hline 27 & Rossyanna & 85 & 83 & 82 & 84 & 75 & 78 & 81 & $\mathrm{~T}$ \\
\hline 28 & Salsabila Putri & 84 & 82 & 81 & 82 & 73 & 75 & 80 & $T$ \\
\hline 29 & Zaafera Aqila A. & 86 & 84 & 82 & 81 & 72 & 74 & 80 & $\mathrm{~T}$ \\
\hline & Zara Tian Putri & 80 & 78 & 82 & 81 & 70 & 70 & 77 & $\mathrm{~T}$ \\
\hline & Rata-Rata & 85 & 83 & 82 & 83 & 73 & 76 & 80 & \\
\hline Jur & lah & & & & & & & 2403 & \\
\hline Nils & i Tertinggi & & & & & & & 82 & \\
\hline Nila & i Terendah & & & & & & & 74 & \\
\hline $\mathbf{R a}$ & - Rata Nilai Akhir & & & & & & & 80 & \\
\hline Per & sentase Ketuntasan & & & & & & & $93 \%$ & \\
\hline
\end{tabular}


Hasil tes lompat jauh Siswa Kelas II SD Negeri 76/IX Muaro Jambi pada kegiatan siklus I disajikan dalam bentuk diagram batang, untuk lebih jelasnya dapat dilihat pada gambar 3 .

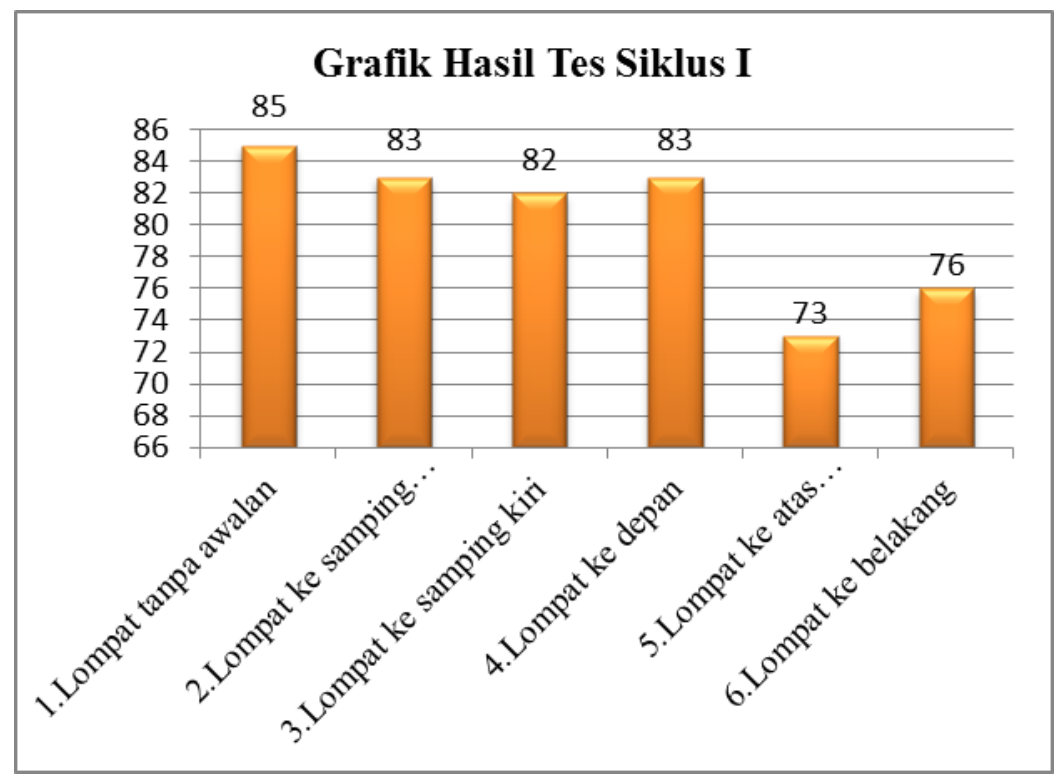

\section{Gambar 3. Diagram Batang Hasil Tes Gerak Dasar Lompat pada Siklus I}

Berdasarkan hasil tes siklus I diperoleh nilai rata-rata sebesar 80. Jumlah siswa yang mencapai KKM hanya sebanyak 28 siswa (93\%) dan siswa yang belum mencapai KKM sebanyak 2 siswa (7\%). Berdasarkan hasil tersebut, siswa sudah memenuhi ketercapaian KKM, yaitu lebih dari $75 \%$ siswa yang tuntas, maka penelitian dianggap berhasil. Dengan latihan akan meningkatkan hasil belajar siswa (Yanto, A. H., 2019). Selain meningkat hasil belajar berolahraga juga dapat meningkatkan gaya hidup sehat (Wibowo, Y. G., \& Indrayana, B. 2019). Dengan metode yang tepat hasil belajar siswa akan meningkat (Susanti, T., \& Hidayat, H.,2017). Strategi pembelajaran yang tepat akan meningkatkan hasil belajar siswa (Purba, T. H., Sipayung, M., \& Lumbangaol, A.,2016).

\section{KESIMPULAN}

Setelah dilakukan penelitian tindakan kelas pada siklus pertama dan dilakukan analisis dapat disimpulkan bahwa peningkatan hasil lompat jauh melalui bermain lompat lingkar berwarna pada siswa kelas II SD Negeri 76/IX Muaro Jambi ditandai dengan peningkatan nilai rata-rata siswa. Nilai rata-rata siswa pada kegiatan pratindakan sebesar $60 \%$ dengan persentase ketuntasan sebesar $40 \%$. Kondisi tersebut mengalami peningkatan nilai rata-rata siswa pada siklus I dengan persentase ketuntasan sebesar $93 \%$. Hal tersebut menunjukkan bahwa target yang telah ditetapkan sebelumnya sudah tercapai sehingga penelitian dilakukan hanya satu siklus saja. Proses pembelajaran gerak dasar lompat menggunakan pendekatan 
bermain berlangsung dinamis dan menyenangkan. Peserta didik aktif melaksanakan tugas dan mengamati gerakan teknik gerak dasar lompat dan saling diskusi dengan teman. Seluruh aspek penilaian dikuasai peserta didik. Kemampuan gerak dasar lompat peserta didik meningkat dengan ditandai hampir seluruh peserta didik tuntas KKM (Kriteria Ketuntasan Minimal) yaitu 75.

\section{DAFTAR PUSTAKA}

Christiari, A. Y., Syamlan, R., \& Kusuma, I. F. (2013). Hubungan pengetahuan ibu tentang stimulasi dini dengan perkembangan motorik pada anak usia 6-24 bulan di Kecamatan Mayang Kabupaten Jember. e-Journal Pustaka Kesehatan, 1(1), 20-23.

Dimyati dan Mudjiono. (1999). Belajar dan Pembelajaran. Jakarta: Rhineka Cipta.

E Mulyasa. (2009). Praktik PTK. Bandung: Remaja Rosdakarya.

Eddy Purnomo. (2007). Gerak Dasar Atletik. Universitas Negeri Yogyakarta. I Made

Farida, A. (2016). Urgensi Perkembangan Motorik Kasar Pada Perkembangan Anak Usia Dini. JURNAL RAUDHAH, 4(2).

Handoko, A. H., \& Pandiangan, D. S. (2019). PENGEMBANGAN PAPAN TUMPUAN DALAM PEMBELAJARAN LOMPAT JAUH. Indonesian Journal of Sport Science and Coaching, 1(2), 65-74.

Joyce, B., Marsha Weil and Emily Calhoun. (2000). Models of Teaching. Boston: Allyn and Bacon Edisi ke-6.

Murniasari. (2008). Atletik. Jakarta: Ganeka.

Pardjono, dkk. (2007). Panduan Penelitian Tindakan Kelas. Yogyakarta: Lembaga Penelitian Universitas Negeri Yogyakarta.

Purba, T. H., Sipayung, M., \& Lumbangaol, A. (2016). Inovasi Pembelajaran Metode Konvensional Dikombinasikan Dengan Strategi Peta Konsep (Concept Mapping) Untukmeningkatkanhasil Belajar Biologi Pada Sub Materi Pokok Sistem Indera Manusia Di Kelas Xi IPA 3 SMA Negeri 3 Binjai Tahun Pembelajaran 2012/2013. BIODIK, 2(2), 73-85. https://doi.org/10.22437/bio.v2iNo\%202.4919

Purwandini, K., \& Kartasurya, M. I. (2013). Pengaruh pemberian Micronutrient Sprinkle terhadap perkembangan motorik anak stunting usia 12-36 bulan (Doctoral dissertation, Diponegoro University).

Rusli Lutan. (2004). Strategi Pembelajaran Penjas. Jakarta: Universitas Terbuka. Saeful Azwar. (2000) Strategi Belajar Mengajar. Jakarta Universitas Terbuka.

Sajoto. (1988). Peningkatan dan Pembinaan Kekuatan Kondis Fisik Dalam Olahraga, Semarang, Dahara Prize.

Soetoto Pontjopoetro. (2002).Lompat Tali. (http://indoshvong. blogspot. com/2010//). Diunduh pada tanggal 12 September 2014.

Susanti, T., \& Hidayat, H. (2017). Pengaruh Metode Resitasi Terhadap Hasil Belajar 
Biologi Siswa Kelas XI Sekolah Menengah Atas Negeri 1 Tanjung Jabung

Timur. BIODIK, 3(2), 53-59. https://doi.org/10.22437/bio.v3i2.5497.

Subagiyo, dkk. (2003). Perencanaan Pembelajaran Penjas. Jakarta: Universitas

Terbuka.

Suharsimi Arikunto. (2002). Penelitian Suatu Pendekatan Praktik. Jakarta: PT. Rineka Cipta.

Sukardi. (1983). Bimbingan Penyuluhan. Surabaya: Usaha Nasional.

Sumadi Suryabrata. (2002). Belajar dan Pembelajaran. Jakarta: Rajawali Pers.

Syaiful Bahri. (1994). Strategi Pembelajaran. Jakarta: Depdiknas.

Tim Abdi Guru. (2006). Pendidikan Jasmani dan Kesehatan Kelas IV. Erlangga.

Udin S Winataputra, M.A., dkk. (2004). Strategi Belajar Mengajar. Jakarta: Universitas Terbuka.

Yanto, A. H., (2019). PENGARUH VARIASI LATIHAN SINGLE LEG JUMP TERHADAP PENINGKATAN HASIL LOMPAT JAUH SISWA SMP ISLAM AL-FALAH KOTA JAMBI. Indonesian Journal of Sport Science and Coaching, 1(2), 75-80.

Yudha M. Saputra. (2001). Teori Bermain. Jakarta. Depdiknas.

Wibowo, Y. G., \& Indrayana, B. (2019). Sport: A review of healthy lifestyle in the world. Indonesian Journal of Sport Science and Coaching, 1(1), 30-34. 